\title{
Assessing Environmental Impact Indicators in Road Construction Projects in Developing Countries
}

\author{
Mohamed Marzouk ${ }^{1}$, Eslam Mohammed Abdelkader ${ }^{2}$, Mohamed El-zayat ${ }^{3}$ and \\ Ahmed Aboushady 4 ,* \\ 1 Construction Engineering and Management, Structural Engineering Department, Faculty of Engineering, \\ Cairo University, Giza 12613, Egypt; mmarzouk@staff.cu.edu.eg \\ 2 Structural Engineering Department, Faculty of Engineering, Cairo University, Giza 12613, Egypt; \\ eslamahmedeaa121@gmail.com \\ 3 Integrated Engineering Design Management Program, Cairo University, Giza 12613, Egypt; \\ m_elzyat@aucegypt.edu \\ 4 Building, and Construction Department, Faculty of Engineering, 6 October University, Giza 12585, Egypt \\ * Correspondence: ABOSHADY.AHMED.eng@O6U.edu.eg \\ Academic Editor: Xiang Li \\ Received: 22 February 2017; Accepted: 8 May 2017; Published: 17 May 2017
}

\begin{abstract}
Environmental pollution is considered to be one of the main concerns in the construction industry. Environmental pollution has become a major challenge to construction projects due to the huge amount of pollution caused by construction projects. There are different types of environmental impact indicators, such as the greenhouse gas (GHG) footprint, eutrophication potential (EP), acidification potential (AP), human health $(\mathrm{HH})$ particulate, ozone depletion, and smog. Each of these environmental impact indicators can be linked to different phases of the construction projects. The overall environmental impact indicators can be divided into direct, indirect, and operational emissions. This paper presents a Building Information Modeling (BIM)-based methodology for the assessment of environmental impacts in road construction projects. The model takes into account the overall life cycle of the road construction project, which is divided into: manufacturing phase, transportation phase, construction phase, maintenance phase, operational phase, recycling phase, and deconstruction phase. A case study is presented to demonstrate the applicability of the proposed model. The proposed model solves a major problem for road construction project teams who want to assess the environmental impact indicators associated with their project prior to the start of the execution of their projects.
\end{abstract}

Keywords: sustainability assessment; environmental impact indicators; building information modeling (BIM); primary energy; construction project

\section{Introduction}

Infrastructure construction projects in general and road construction projects specifically are associated with a huge amount of emissions that vary from the start of project execution until the demolition stage [1]. This pollution can affect human health and the economic balance in a very severe matter [2]. Therefore, the issue of sustainability development and Building Information Modeling (BIM) has emerged. It is vital to quantify these emissions to reduce the hazards. This article introduces six different types of road construction environmental impacts: impact on the greenhouse gas (GHG) footprint, impact on acidification potential (AP), human health $(\mathrm{HH})$ particulate, impact on eutrophication potential (EP), impact on ozone depletion, and impact on smog. Different mathematical models exist in literature to assess environmental impact indicators in the construction industry. Abanda et al. [3] developed a review mathematical model of embodied energy, greenhouse gases, and wastes based 
on the time-cost parameters of building projects. Tsai et al. [4] proposed a mathematical programing approach in selecting green building projects. On the other hand, energy has played an important role in the economic growth over the decades. According to Hawken and Lovins [5], the more products are produced, the more natural resources are consumed. Moreover, economic activities require large amounts of energy and material to be consumed and produce more waste in the form of environmental emissions [6]. Rani et al. [2] defined primary energy as "the energy in the form of Natural Gas, Wood, Wind, Hydropower, and Sunlight". Primary energy can be divided into renewable and non-renewable energy. Use of these natural resources during the construction, operation, and maintenance stages of the project is associated with environmental impact indicators. Considering the life cycle of roads, the consumption of primary energy is related to the consumption of electricity used for lighting roads, and the consumption of natural gas, diesel, and gasoline used for operational passenger cars and construction equipment. Different researchers have tackled the issue of sustainability in infrastructure construction projects. Umer et al. [7] developed a sustainability assessment hierarchal model for roadway projects under uncertainties using a green-based index approach to evaluate how well the project meets sustainability objectives in order to illustrate how well the roadway project is meeting its sustainability objectives.

Moreover, different researchers have tackled the issue of environmental analysis. Lim et al. [8] developed an optimization model to reduce environmental impacts and costs in urban water infrastructure projects. Park et al. [9] developed a qualitative assessment model to determine the environmental impacts on life cycle of highways. The model takes into account the four stages: manufacturing of construction materials, construction, maintenance/repair, and the demolition/recycling stage. They found that energy consumption during the maintenance and repair stage was the highest. However, Park et al. [9] did not demonstrate how to compute the environmental impact indicators during the project life cycle. Capiteo et al. [10] developed a model for the pavement materials using warm mix asphalt. Barandica et al. [11] developed a model to reduce the impact of greenhouse gas emissions resulting from road construction using life cycle assessment. They found that earthworks are the main activity involved, and they contribute $60-85 \%$ of the total emissions in the construction stage. They did not take into account the primary energy consumption resulting from road lighting, and fuel consumption resulting from passenger cars and construction equipment.

Furthermore, different researchers have tackled the issue of developing BIM. Marzouk and Abdel Aty [12] developed a model to maintain subway infrastructure using BIM. The model proposed the application of BIM in subways by modeling different components including structural, mechanical, electrical, and Heating, Ventilation, and Air Conditioning (HVAC). Marzouk and Hisham [13] developed a model to control the cost in bridge projects using Building Information Modelling. The model integrates BIM with the earned value (EV) concept to determine the project status at specific reporting date. Marzouk and Abdel Aty [14] developed a model to monitor thermal comfort in subways using BIM. The model presents an application that utilizes a wireless sensor network (WSN) and BIM in order to monitor thermal conditions within a subway. Jullien et al. [15] developed a specific tool called, which is dedicated to road life cycle assessment. The objective of this study is to decrease the amount of consumption of materials, water, and energy through computing their environmental impacts. However, none of the above researchers have assessed environmental impact indicators and primary energy. Moreover, none of above researchers integrated BIM, sustainability assessment, and environmental impact indicators in road construction projects. Therefore, there is a need to develop a model that integrates sustainability assessment, BIM, and environmental impact indicators in road construction projects in Egypt.

The main objective of this paper is to quantify the environmental impact indicators that are associated with road construction project using BIM. This is achieved through the development of Environmental Building Information Modeling (EBIM) model. The model solves a major problem for road construction project teams, who want to identify, and quantify the environmental impact indicators associated with their projects prior to the start of execution of their projects. 


\section{Research Methodology}

The EBIM is composed of seven stages as depicted in Figure 1: (1) identifying environmental impact indicators; (2) identifying project assemblies and life cycle assessment boundaries; (3) developing the BIM module; (4) defining input for time module, cost, and environmental module;

(5) applying environmental emission algorithms; (6) defining output of the proposed model and (7) conducting a comparative case study.

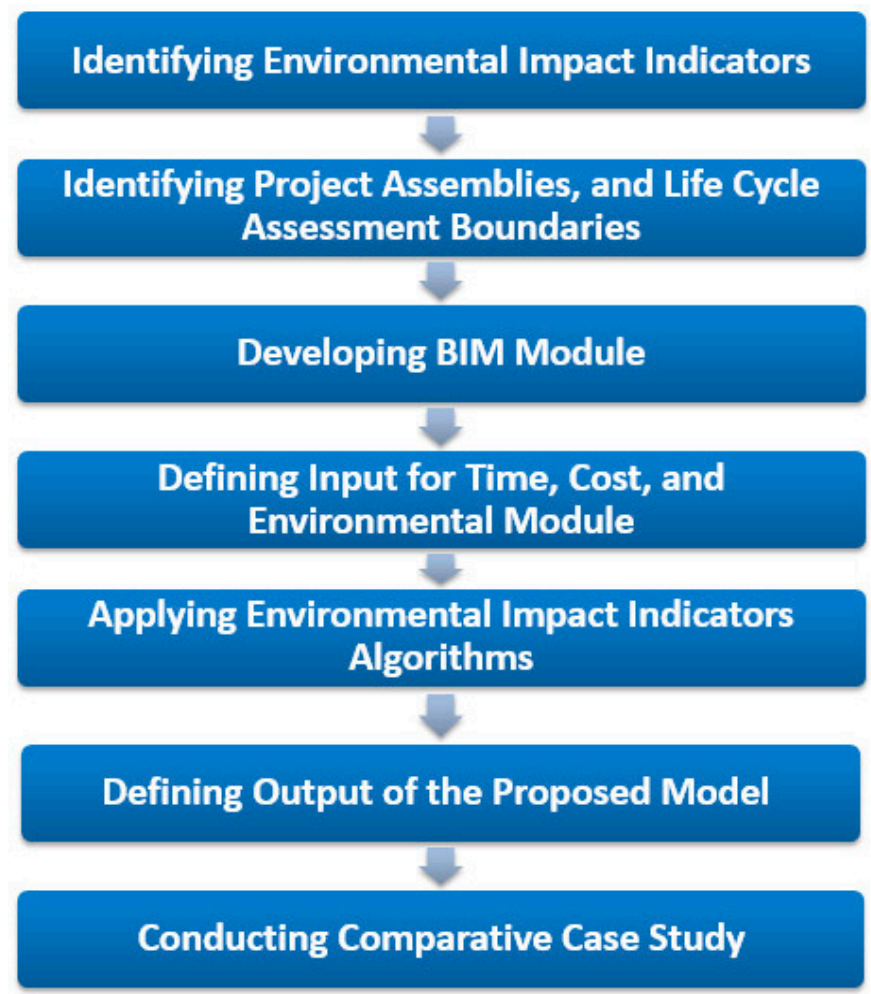

Figure 1. Environmental Building Information Modeling (EBIM) methodology and model development.

\subsection{Identifying Environmental Impact Indicators}

Environmental impact indicators were identified through literature review, and interviews using the indirect method and two-step Delphi technique in order to ensure a consensus level with ten experts, each of them has more than twenty years of experience in road construction projects, and environmental impact assessment. Their status ranged from site engineer to general manager of road construction projects. Experts were asked to provide the following information: "based on your experience in road construction projects, and your experience in environmental impact assessment, please identify the environmental impact indicators encountered in your project". Experts agreed that environmental impact indicators can be divided into: impact on greenhouse gas (GHG) footprint, impact on acidification potential (AP), impact on human heath (HH) particulate, impact on eutrophication potential (EP), impact on ozone depletion, and impact on smog [1,2]. Experts also agreed that these environmental impact indicators should be assessed in terms of direct, indirect, and operational emissions.

\subsection{Identifying Project Assemblies and Life Cycle Assessment Boundaries}

Road construction project activities can be divided into eight activities: performing earthworks, performing fill embankment, placing sub base, placing curbstone, insulating prime coat, insulating tack coat, placing stabilized base coarse, and placing wearing coarse. Each of these activities will be assessed against time needed to execute the activity, life cycle cost, environmental impact indicators, 
and total primary energy consumed by each activity. The proposed model accounts for different project phases which are manufacturing phase, transportation on-site phases, construction phase, maintenance phase, recycling phase, and deconstruction, and demolition phase [16]. The life cycle assessment system boundary identifies the inputs (materials, energy, and equipment) along with the output (emissions) from each step in the process of the life cycle (manufacturing, transportation on-site, construction, maintenance, recycling, and deconstruction, and demolition). Therefore, the system controls the inputs and outputs [17].

\subsection{Developing BIM Module}

The third step of the proposed model is to develop the BIM module using the Autodesk Revit 2015 as an add-on in Revit, and to define systems in Copert 4, and Athena Impact Estimator. The 3D BIM modules constitute the data base that is used to compute the environmental impact indicators in terms time, life cycle cost, overall environmental impact indicators and primary energy associated with road construction processes. Different properties of the construction project should be defined in Copert 4, such as country name, country information, fuel information, vehicle information, input fleet data, and input circulation data. The interface of rule wizard of the Copert 4 software is depicted in Figure 2. The Copert 4 as mentioned above computes the different environmental impacts for the construction project, such as impact on greenhouse gas (GHG) footprint, impact on acidification potential (AP), impact on human health $(\mathrm{HH})$ particulate, impact on eutrophication potential (EP), impact on ozone depletion, and impact on smog with regard to different life cycles of the construction project. Copert 4 Output is in Excel Format.

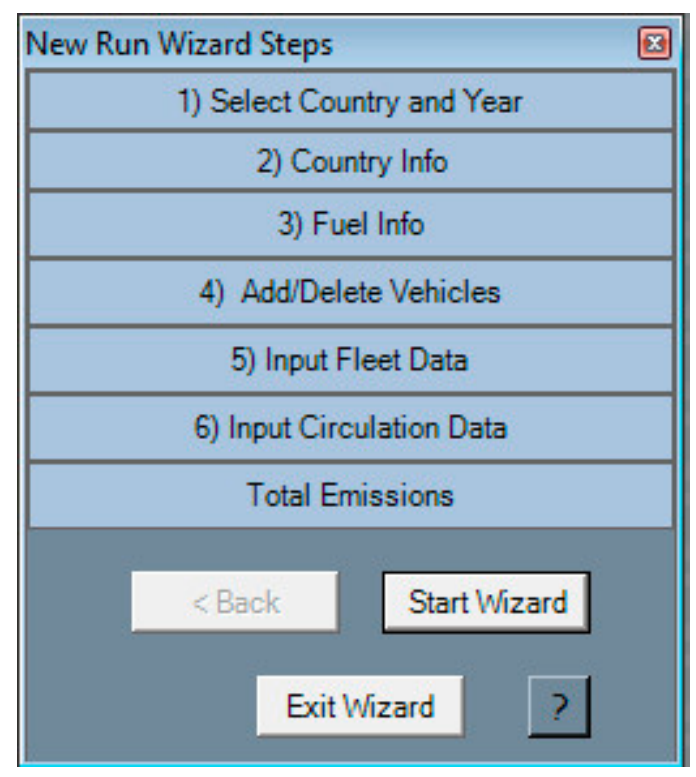

Figure 2. Rule Wizard of the Copert 4 Software.

\subsection{Defining Input for Time Module, Cost, and Environmental Module}

The proposed application computes time, life cycle cost, environmental impact, and primary energy for the construction project. The module is divided into three divisions, which are the time division, cost division, and environmental division. The user is asked to enter certain inputs in each division. The user is asked to enter number of crews, productivity of the crew, and nature of the crew (single-based crew, or ranged-based crew) for the time division.

The input for time division is the quantity of work to be performed, the productivity of the crew in performing the task, the efficiency of the crew in performing the task, and the number of the crews available for performing the task. Figure 3 illustrates an example of the time division. For the 
environmental division, the user is asked to enter relative weights of six different environmental impact indicators (W1, W2, W3, W4, W5, and W6). Figure 4 illustrates an example of the interface of the environmental division.

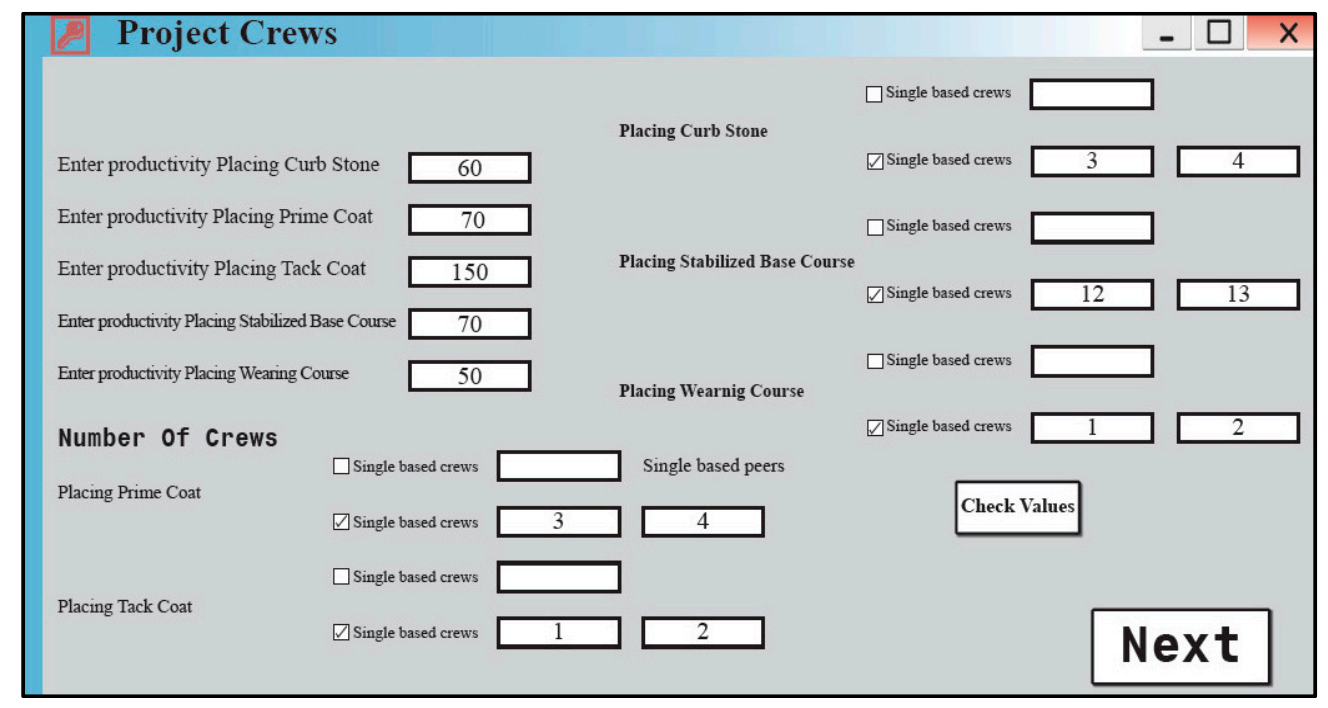

Figure 3. User input for the time module interface.

As illustrated in Figure 3, the interface asks the user to enter the productivity of road crew in performing each activity. The system asks the user to specify the number of crews in performing each activity, and whether it is a single crew type or a single based peer's crew. The "check values" button enables the user to check the entries before submitting to the system. For the cost division, the user is asked to enter some information regarding the cost in order to be able to compute the life cycle cost of the construction project, such as minimum attractive rate of return (MARR), maintenance cost per year (if applicable), maintenance cost per specific period of time (if applicable), and the life span, for example, 25, 50, and 100 years. Then, the user is asked to enter the maintenance cost at a specific year (if applicable.).

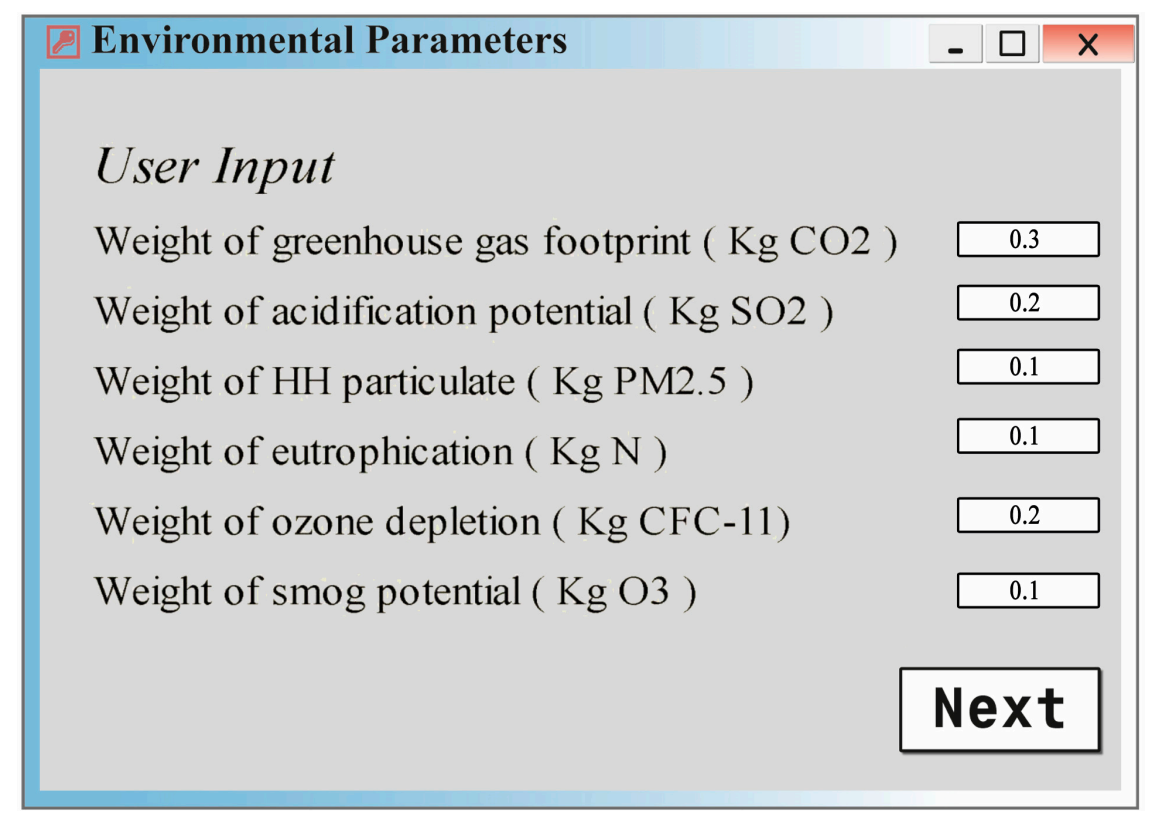

Figure 4. User input for the environmental module interface. 
As illustrated in Figure 4, the interface of the system asks the user to specify the relative weights of six different environmental impact indicators (W1, W2, W3, W4, W5, and W6). These weights were obtained from the database of a road construction company performing project 4 presented in the case study section.

\subsection{Applying Environmental Emission Algorithms}

The fifth step is to compute the environmental impacts. The proposed model computes time, life cycle cost, environmental impacts, and primary energy. Time is computed based on the quantity of work to be performed, the productivity of the crew in performing the task, the efficiency of the crew, and the number of the crews available for performing the task.

\subsubsection{Computations of Environmental Impact Indicators}

The overall environmental impacts of road construction project can be classified into three major categories: direct, indirect, and operational emissions. The overall environmental impacts equal the summation of the direct, indirect, and operational emissions. The direct emission can be defined as "the emissions that are directly related to on-site construction processes ... computed based on the amount of fuel consumed from equipment during the construction process" [1]. The direct emissions are equal to the construction emission in addition to transportation emissions, recycling, deconstruction emissions, and repair/maintenance emissions. The total direct emissions are computed based in Equation (1).

$$
\mathrm{Ed}=\mathrm{T} 1 \times\left(\frac{\text { Eghg }}{\text { Eghgsum }}\right)+\mathrm{T} 2 \times\left(\frac{\text { Eap }}{\text { Eapsum }}\right)+\mathrm{T} 3 \times\left(\frac{\text { Ehh }}{\text { Ehhsum }}\right)+\mathrm{T} 4 \times\left(\frac{\text { Eep }}{\text { Eepsum }}\right)+\mathrm{T} 5 \times\left(\frac{\text { Eod }}{\text { Eodsum }}\right)+\mathrm{T} 6 \times\left(\frac{\text { Es }}{\text { Es sum }}\right)
$$

where; Ed refers to the total direct emissions, T1, T2, T3, T4, T5, and T6 refer to the modification index of impact on the greenhouse gas (GHG) footprint, impact on acidification potential (AP), impact on human health $(\mathrm{HH})$ particulates, impact on eutrophication potential (EP), impact on ozone depletion, and impact on smog, respectively. Each modification index is equal to the severity index multiplied by corresponding weighted percentage. Eghg, Eap, Ehh, Eep, Eod, and Es represent potentials produced from the construction, transportation-on site, maintenance, deconstruction, and demolition phases of the construction project, respectively. Eghgsum, Eapsum, Ehhsum, Eepsum, Eodsum, and Es sum represent the potentials sums for the construction project, including the direct and indirect emissions for impact on the greenhouse gas (GHG) footprint, impact on acidification potential (AP), impact on human health $(\mathrm{HH})$ particulates, impact on eutrophication potential $(\mathrm{EP})$, impact on ozone depletion, and impact on smog, respectively. Six parameters weights (W1, W2, W3, W4, W5, and W6) are assigned to each type of the environmental impact indicators. These weighted percentages are the percentage of impact on greenhouse gas (GHG) footprint, impact on acidification potential (AP), impact on human health $(\mathrm{HH})$ particulates, impact on eutrophication potential (EP), impact on ozone depletion, and impact on smog, respectively. The sum of the weighted percentages should equal to 1 . Table 1 lists the severity index of each environmental parameter on human health.

Table 1. Proposed values for the severity index [1].

\begin{tabular}{cc}
\hline Severity of the Environmental Parameter & Quantitative Measure \\
\hline Very high & $8-10$ \\
High & $6-8$ \\
Medium & $4-6$ \\
Low & $2-4$ \\
Very low & $1-2$ \\
\hline
\end{tabular}

The above-mentioned figures in Table 1 (severity index) will be used to compute the modification index ( $\mathrm{T}$ ) for different environmental impacts presented in Equation (1) by multiplying the severity index with the weighted percentage (W). The greenhouse gas (GHG) footprint produced from the 
construction site $\left(\right.$ Eghg $\left.^{\mathrm{c}}\right)$, transportation $\left(\right.$ Eghg $\left.^{\mathrm{t}}\right)$, deconstruction $\left(\right.$ Eghg $\left.^{\mathrm{d}}\right)$, and maintenance $\left(\right.$ Eghg $\left.^{\mathrm{m}}\right)$ is computed using Equations (2)-(5).

$$
\begin{aligned}
& \operatorname{Eghg}^{c}=\sum_{j=1}^{n} \text { Cons AVG }(j) \times \text { Working hours }(j) \times \operatorname{Act~Work~}(j) \times \gamma_{\text {diesel }} \times C E F \times T(j) \\
& \text { Eghg }^{\mathrm{t}}=\sum_{\mathrm{j}=1}^{\mathrm{n}} \text { Cons } \mathrm{AVG}(\mathrm{j}) \times \text { Working hours }(\mathrm{j}) \times \operatorname{Act} \operatorname{Work}(\mathrm{j}) \times \gamma \operatorname{diesel} \times \mathrm{CEF} \times \mathrm{T} \operatorname{tra}(\mathrm{I}) \\
& \operatorname{Eghg}^{\mathrm{d}}=\sum_{\mathrm{j}=1}^{\mathrm{n}} \operatorname{Cons} \operatorname{AVG}(\mathrm{j}) \times \operatorname{Working} \operatorname{hours}(\mathrm{j}) \times \operatorname{Act} \operatorname{Work}(\mathrm{j}) \times \gamma_{\operatorname{diesel}} \times \mathrm{CEF} \times \mathrm{T}(\mathrm{j}) \\
& \operatorname{Eghg}^{m}=\sum_{j=1}^{n} \text { Cons AVG }(j) \times \operatorname{Working} \operatorname{hours}(j) \times \operatorname{Act} \operatorname{Work}(j) \times \gamma \operatorname{diesel} \times C E F \times T(j)
\end{aligned}
$$

where $\mathrm{j}$ is the number of equipment used in construction for a specific construction element. I is the number of equipment used in transportation process in site. Cons AVG refers to the average consumption of certain equipment (liters/hour). Working hours are number of working hours of the equipment (typically $8 \mathrm{~h}$ /day). Act Work is the percentage of the equipment that will actually work, which is approximated to be $70 \%$ of the working hours of the equipment $[18,19]$. $\gamma$ diesel is the density of diesel, which is $0.832 \mathrm{Kg} / \mathrm{I}$. CEF is the carbon emission factor for diesel, which is $4 \mathrm{Kg}$ $\mathrm{CO}_{2}-\mathrm{Eq} / \mathrm{Kg}$ [19]. T-tra refers to transportation time for certain equipment for diesel. T refers to the time for executing the task. Table 2 illustrates the average consumption (Cons AVG) of some equipment [20]. A conversion factor is used to convert from gallons to liters, where 1 gallon $=3.785 \mathrm{~L}$.

Table 2. Average fuel consumption of construction equipment.

\begin{tabular}{cc}
\hline Construction Equipment & Average Fuel Consumption (Gallons/Hour) \\
\hline Caterpillar 936 Loader & 3.5 \\
Caterpillar D5 Dozer & 4 \\
Dump Truck, 12 cubic yards & 5.34 \\
Crane, 45 tonnes & 4 \\
Caterpillar 815 Roller & 10.25 \\
Caterpillar 325 Back hole & 5.12 \\
\hline
\end{tabular}

$\mathrm{T}$ is the time need to execute the construction activity, which is computed using Equation (6) [1].

$$
\mathrm{T}=\frac{\text { Quantity of work to be performed }}{\text { (Productivity of sin gle Equipment } \times \text { efficiency } \times \text { number items of Equipments })}
$$

where efficiency is assumed to be $80 \%$ [21,22].

Indirect emissions refer to "emissions that are produced off-site construction processes" [1]. They include manufacturing, transportation off site emissions, and operation. The indirect emissions are computed using Equation (7):

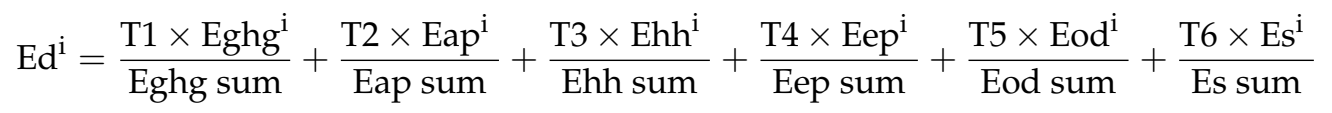

where Eghg ${ }^{i}$, Eap $^{i}, E h^{i}{ }^{i} \operatorname{Eep}^{i}$, Eod $^{i}$, and $\mathrm{Es}^{i}$ represent potentials produced from material production, and transportation off-site phases for impact on the greenhouse gas (GHG) footprint (equivalent carbon dioxide), impact on acidification potential (AP), impact on human health (HH) particulates, impact on eutrophication potential (EP), impact on ozone depletion, and impact on smog, respectively. 
Operational emissions are the emissions produced from daily operation of the facility after being constructed till the end of its remaining life cycle [23]. They are produced from four main sources: electricity, natural gas, diesel, and gasoline. The operational emissions resulted from the consumption of electricity used for lighting the road, and from the consumption of different types of fuels used by passenger cars, and construction equipment during the operational stage. The total operational emissions are the sum of the operational emissions resulting from the impact on greenhouse gases (GHGs), impact on sulfur dioxide, impact on particulate matter, and impact on smog. The total quantity of carbon dioxide can be computed by multiplying quantity of each greenhouse gas by global warming ( $\mathrm{g}$ ) of the potential. Operational emissions can be calculated using Equation (8). Operational emissions of sulfur dioxide can be calculated using Equation (9). Operational emissions of particulate matter can be calculated using Equation (10). Operational emissions of smog can be calculated using Equation (11) [1]. Table 3 lists the global warming potential over a 100-year period. Table 4 lists the emissions factors of different emissions from electricity consumption. Table 5 lists the emissions factors of different emissions from natural gas consumption.

$$
\begin{gathered}
(\text { Eghg })^{\text {op }}=((\text { EF ELEC }(\mathrm{j}) \text { ghg } \times \text { Cons elec })+(\text { EF NGAS }(j) \text { ghg } \times \text { Cons ngas })) \times \text { GWP }(j) \\
(\text { Epm })^{\text {op }}=((\text { EF ELEC pm } \times \text { Cons elec })+(\text { EF NGAS pm } \times \text { Cons ngas })) \\
(\text { Eap })^{\text {op }}=((\text { EF ELEC ap } \times \text { Cons elec })+(\text { EF NGAS ap } \times \text { Cons ngas })) \\
(\text { Es })^{\text {op }}=((\text { EF ELEC } \mathrm{s} \times \text { Cons elec })+(\text { EF NGAS } \mathrm{s} \times \text { Cons ngas }))
\end{gathered}
$$

where Cons elec, and Cons nags are the total amount of electricity consumption and natural gas consumption, respectively, over the life span of the construction project, which is equal to the average consumption of electricity, and natural gas consumption multiplied by the area of the construction project and lifespan of the facility, which is assumed to be 50 years. EF ELEC (j) ghg, EF ELEC pm, EF ELEC $_{\text {ap }}$, and EF ELEC $s$ represent potential emissions factors produced from electricity consumption of impact on the greenhouse gas (GHG) footprint, impact on human health ( $\mathrm{HH}$ ) particulate matter, impact on acidification potential (AP), and impact on smog, respectively. EF NAGS (j) ghg, EF NAGS pm, EF NAGS ${ }_{\text {ap }}$, and EF NAGS s represent potential emissions factors produced from natural gas consumption with respect to the impact on the greenhouse gas (GHG) footprint, impact on human health $(\mathrm{HH})$ particulate matter, impact on acidification potential (AP), and impact on smog, respectively. The total operational emissions are the sum of emissions produced from potential emissions of impact on the greenhouse gas (GHC) footprint, impact on human health $(\mathrm{HH})$ particulate matter, impact on acidification potential (AP), and impact on smog.

Table 3. Values of global warming potential (adapted from [24]).

\begin{tabular}{cc}
\hline Greenhouse Gases & Global Warming Potential \\
\hline Carbon dioxide & 1 \\
Methane & 21 \\
Nitrous oxide & 310 \\
\hline
\end{tabular}

Table 4. Emission factors of pollutants from electricity consumption (adapted from [25]).

\begin{tabular}{cc}
\hline Pollutant & Emission Factor $(\mathrm{g} / \mathrm{Kwh})$ \\
\hline Carbon dioxide & 700 \\
Methane & 0.01 \\
Nitrous oxide & 0.09 \\
Sulfur dioxide & 2 \\
Particular matter & 0.1 \\
Volatile organic compound & 0.44 \\
Nitrogen oxide & 1 \\
\hline
\end{tabular}


Table 5. Emission factors of pollutants from natural gas consumption (adapted from [26]).

\begin{tabular}{cc}
\hline Pollutant & Emission Factor (g/Kwh) \\
\hline Carbon dioxide & 55.5 \\
Methane & 0.001 \\
Nitrous oxide & 0.002 \\
Sulfur dioxide & 0.001 \\
Particular matter & 0.001 \\
Volatile organic compound & 0.005 \\
Nitrogen oxide & 0.17 \\
\hline
\end{tabular}

In order to cope with the problem of electricity grid mix varies from one country to another, the International Energy Association IEA [27] stated that the energy balance of a country can be used to suggest a rough estimate of emission factors generated from energy consumption in conjunction with the share of electricity industry generating air pollutants. For example, the Misr State Environmental Association MSEA [28] reported that $60 \%$ of $\mathrm{CO}_{2}$ emissions in Egypt (as an example of developing country) is generated by the electricity industry. Therefore, the energy balance can be used as a method to determine emission factors in the case that there is not sufficient data. The overall environmental impacts for each single phase in construction can be calculated using Equation (12).

$$
(\mathrm{E})^{\mathrm{tot}}=(\mathrm{Ed})+\left(\mathrm{Ed}^{\mathrm{i}}\right)
$$

where $\mathrm{Ed}$, and $\mathrm{Ed}^{\mathrm{i}}$ represent the direct and indirect emissions, respectively.

The global environmental impacts can be computed using Equation (13).

$$
(E)^{\text {global }}=(E d)+\left(E^{\mathrm{i}}\right)+\left(\mathrm{Ed}^{\mathrm{op}}\right)
$$

where $\mathrm{Ed}, \mathrm{Ed}^{\mathrm{i}}$, and $\mathrm{Edo}^{\mathrm{p}}$ represent the direct, indirect, and operational emissions, respectively.

\subsubsection{Computations of Life Cycle Cost}

The life cycle cost is an equivalent annual worth for different cost components, which is computed using minimum attractive rate of return (MARR). The life cycle cost is calculated using Equation (14):

$$
\text { TLCC }=\text { LCC lab + LCC equip + LCC mat + Lcc main1 + LCC main2 + LCC sing }
$$

where TLCC refers to the total life cycle cost. LCC lab, LCC equip, LCC mat, LCC main1, LCC main2, and LCC sing refer to the equivalent annual worth for labor cost, equipment cost, material cost, maintenance cost/year, maintenance cost/period of time, and single payment, respectively.

\subsubsection{Computations of Primary Energy}

The primary energy is the sum of the primary energy consumed resulted from electricity, natural gas consumptions, and the consumption of oil during the different stages of the project, which is measured in megajoule (MJ) units. The overall primary energy is computed using Equation (15) [29]:

$$
\mathrm{TPE}=\mathrm{PE} \text { manu }+\mathrm{PE} \text { tra }- \text { off }+\mathrm{PE} \text { cons }+\mathrm{PE} \text { oper }+\mathrm{PE} \text { dec }+ \text { PE rec }
$$

where TPE refers to the total primary energy. PE manu, PE tra-off, PE cons, PE tra-on, PE oper, PE dec, and PE rec refer to primary energy consumed in manufacturing stage, transportation off-site stage, construction stage, transportation on-site stage, operation and maintenance stage, deconstruction stage, and recycling and reuse stage, respectively. There are two main sources for primary energy in the operational stage: electricity consumption, natural gas consumption, and the consumption of oil during different stages of the project. The total electricity consumption during operational stage can 
be computed using Equation (16) [2]. The total natural gas consumption during the operational stage can be determined using Equation (17) [2].

$$
\begin{gathered}
\text { TEC }=\text { Cons elec } \times \text { SA } \times \text { number of years } \\
\text { TNGC }=\text { Cons nags } \times \text { SA } \times \text { number of years }
\end{gathered}
$$

where TEC, TNGC refer to the total electricity and natural gas consumption produced during the operational stage, respectively. SA refers to the total surface area of the construction project. The annual electricity consumption is assumed to be $200 \mathrm{KW} / \mathrm{m}^{2}$ [29]. The annual natural gas consumption is assumed to be $28 \mathrm{~m}^{3} / \mathrm{m}^{2}$ (this amount was computed based on data on the amount of natural gas production in Egypt in 2013, the percentage of natural gas consumed in electricity generation in Egypt, and the total surface area of paved and unpaved roads) [30]. TEC, and TNGC are measured in megajoules. A conversion factor is used to convert from $\mathrm{m}^{3} / \mathrm{m}^{2}$ of natural gas to $\mathrm{KWh} / \mathrm{m}^{2}$ where $1 \mathrm{~m}^{3} / \mathrm{m}^{2}$ of natural gas equals $10.55 \mathrm{KWh} / \mathrm{m}^{2}$ [31,32].

\subsubsection{Numerical Example}

The following data was obtained during the site visit for project 1 (Asyut/Sohag/Red Sea) presented in Table 6 in the case study section. The length of the project is $180 \mathrm{Km}$ with a total cost of 1.156 billion L.E., and the project is estimated to finish on 31 March 2016. In this case, W1 = 0.4, $\mathrm{W} 2=0.1, \mathrm{~W} 3=0.1, \mathrm{~W} 4=0.2, \mathrm{~W} 5=0.1$, and $\mathrm{W} 6=0.1$. The severity index from Table 1 of $\mathrm{T} 1=8$ (high), the severity index of T2 $=6$ (medium), the severity index of T3 $=4(\mathrm{low})$, the severity index of T4 $=4$ (low), the severity index of T5 $=2$ (very low), and the severity index of T6 $=10$ (very high). Therefore:

$$
\begin{aligned}
& \mathrm{T} 1=\mathrm{W} 1 \times \text { Severity Index }=0.4 \times 8=3.2 \\
& \mathrm{~T} 2=\mathrm{W} 2 \times \text { Severity Index }=0.1 \times 6=0.6 \\
& \mathrm{~T} 3=\mathrm{W} 3 \times \text { Severity Index }=0.1 \times 4=0.4 \\
& \mathrm{~T} 4=\mathrm{W} 4 \times \text { Severity Index }=0.2 \times 4=0.8 \\
& \mathrm{~T} 5=\mathrm{W} 5 \times \text { Severity Index }=0.1 \times 2=0.2 \\
& \mathrm{~T} 1=\mathrm{W} 6 \times \text { Severity Index }=0.1 \times 10=1.0
\end{aligned}
$$

The amount of Eghg produced from project 1 (construction, and transportation on-site phase) in performing the earthworks activity is $598.8 \mathrm{Kg} \mathrm{CO}_{2} \mathrm{Eq}$, Eghg sum is $80,140 \mathrm{Kg} \mathrm{CO}_{2}$-Eq, Eap is $297 \mathrm{Kg}$ $\mathrm{SO}_{2}$, Eap sum is $11,360 \mathrm{Kg} \mathrm{SO}_{2}$, Ehh is $128 \mathrm{Kg} \mathrm{PM}_{2.5}$, Ehh sum is $9100 \mathrm{Kg} \mathrm{PM}_{2.5}$, Eep is $100 \mathrm{Kg} \mathrm{N}$, Eep sum is $9520 \mathrm{Kg} \mathrm{N}$, Eod is $100 \mathrm{Kg}$ CFC-11, Eod sum is $550 \mathrm{Kg}$ CFC-11, Es is $400 \mathrm{Kg} \mathrm{O}_{3}$, and the Es sum is $37,885 \mathrm{Kg} \mathrm{O}_{3}$. Then, by applying Equation (1):

Total direct emissions:

$$
\begin{gathered}
(\mathrm{Ed})=3.2(598.8 / 80,140)+0.6(297 / 11,360)+0.4(128 / 9100)+0.8(100 / 9520)+ \\
0.2(100 / 550)+1(400 / 37,885)=0.1054 \mathrm{Kg} \mathrm{CO}_{2}-\mathrm{Eq}
\end{gathered}
$$

The amount of earthworks to be performed is $1000 \mathrm{~m}^{3} /$ day, the productivity of the single excavator is $70 \mathrm{~m}^{3}$ /day, and the number of items of equipment used is 6, applying Equation (6):

$\mathrm{T}($ time needed to execute a construction activity $)=1000 /(70 \times 0.8 \times 6)=2.98$ days $=3$ days

If the quantity of waste that will be dumped is $2000 \mathrm{~m}^{3} /$ day, the productivity of single equipment is $70 \mathrm{~m}^{3} /$ day, efficiency $=0.8$, and number of items of equipment $=5$, then,

$$
\mathrm{T} \text { tra }=2000 /(70 \times 0.8 \times 5)=7.143=8 \text { days }
$$


Assume that the average consumption of fuel (gallon/ hour) from Table 2 is 3.5 gallons/hour and this amount is converted to $13.25 \mathrm{~L}$. The number of working hours is $8 \mathrm{~h} /$ day, and the actual work hours represent $70 \%$ of this. $\gamma$ diesel is $0.832 \mathrm{~kg} / \mathrm{I}$, and the carbon emission factor $(\mathrm{CEF})=4 \mathrm{~kg}$ $\mathrm{CO}_{2}-\mathrm{Eq} / \mathrm{Kg}$, Tis 6 days. By applying Equations (2) and (3):

$$
\begin{gathered}
\text { Eghg }^{\mathrm{c}}=13.25 \times 8 \times 0.7 \times 0.832 \times 4 \times 6=1481.63 \mathrm{~L} \mathrm{Kg} \\
\text { Eghg }^{\mathrm{t}}=13.25 \times 8 \times 0.7 \times 0.832 \times 4 \times 8=1975.5 \mathrm{~L} \mathrm{~kg}
\end{gathered}
$$

In order to compute the total in direct emissions, $\mathrm{W} 1=0.4, \mathrm{~W} 2=0.1, \mathrm{~W} 3=0.1, \mathrm{~W} 4=0.2, \mathrm{~W} 5=0.1$, and $\mathrm{W} 6=0.1$; the severity index from table of $\mathrm{T} 1=8$ (High), the severity index of $\mathrm{T} 2=6$ (medium), the severity index of T3 $=4$ (low), the severity index of $\mathrm{T} 4=4$ (low), the severity index of $\mathrm{T} 5=2$ (very low), and the severity index of T6 $=10$ (very high). Then:

$$
\begin{array}{r}
\mathrm{T} 1=\mathrm{W} 1 \times \text { Severity Index }=0.4 \times 8=3.2 \\
\mathrm{~T} 2=\mathrm{W} 2 \times \text { Severity Index }=0.1 \times 6=0.6 \\
\mathrm{~T} 3=\mathrm{W} 3 \times \text { Severity Index }=0.1 \times 4=0.4 \\
\mathrm{~T} 4=\mathrm{W} 4 \times \text { Severity Index }=0.2 \times 4=0.8 \\
\mathrm{~T} 5=\mathrm{W} 5 \times \text { Severity Index }=0.1 \times 2=0.2 \\
\mathrm{~T} 1=\mathrm{W} 6 \times \text { Severity Index }=0.1 \times 10=1.0
\end{array}
$$

The amount of Eghg produced from project 1 (manufacturing, and transportation off-site phase) is $17,000 \mathrm{Kg} \mathrm{CO}_{2}$-Eq, Eghg sum is $80,140 \mathrm{Kg} \mathrm{CO}_{2}$-Eq, Eap is $7850 \mathrm{Kg} \mathrm{SO}_{2}$, Eap sum is $11,360 \mathrm{Kg} \mathrm{SO}_{2}$, Ehh is $7550 \mathrm{Kg} \mathrm{PM}_{2.5}$, Ehh sum is $9100 \mathrm{Kg} \mathrm{PM}_{2.5}$, Eep is $7950 \mathrm{~kg} \mathrm{~N}$, Eep sum is $9520 \mathrm{Kg} \mathrm{N}$, Eod is $8820 \mathrm{Kg}$ CFC-11, Eod sum is 10,530 Kg CFC-11, and Es is $19,250 \mathrm{Kg} \mathrm{O}_{3}$, and Es sum is $37,885 \mathrm{Kg} \mathrm{O}_{3}$, then by applying Equation (7):

Total of direct emissions:

$$
\begin{gathered}
\left(\mathrm{Ed}^{\mathrm{i}}\right)=3.2(17,000 / 80,140)+0.6(7850 / 11,360)+0.4(7550 / 9100)+0.8(7950 / 9520)+ \\
0.2(8820 / 10,530)+1(19,250 / 37,885)=2.7711 \mathrm{Kg} \mathrm{CO}_{2}-\mathrm{Eq}
\end{gathered}
$$

Based on data gathered from interviews in the project, Global Warming Potential GWP is 1 from Table 3, Cons-elec for carbon dioxide is $700 \mathrm{~g} / \mathrm{kwh}$ from Tables 4 and 5, Cons-elec for sulfur dioxide is $0.09 \mathrm{~g} / \mathrm{kwh}$, Cons-elec for particulate matter is $2 \mathrm{~g} / \mathrm{kwh}$, Cons-elec for smog is $1.44 \mathrm{~g} / \mathrm{kwh}$, Cons-Ngas for carbon dioxide is $55.5 \mathrm{~g} / \mathrm{kwh}$, Cons-Ngas for sulfur dioxide is $0.001 \mathrm{~g} / \mathrm{kwh}$, Cons-Ngas for particulate matter is $0.001 \mathrm{~g} / \mathrm{kwh}$, and Cons-Ngas for smog is $0.175 \mathrm{~g} / \mathrm{kwh}$. These amounts should be multiplied by the life span of the project, which is 50 years.

$$
\begin{gathered}
\text { Cons-elect for carbon dioxide }=700 \times 50=35,000 \mathrm{~g} / \mathrm{kwh} \\
\text { Cons-Ngas for carbon dioxide }=55.5 \times 50=2775 \mathrm{~g} / \mathrm{kwh} \\
\text { Cons-elect for sulfur dioxide }=0.09 \times 50=4.5 \mathrm{~g} / \mathrm{kwh} \\
\text { Cons-Ngas for sulfur dioxide }=0.001 \times 50=0.05 \mathrm{~g} / \mathrm{kwh} \\
\text { Cons-elect for particular matter }=2 \times 50=100 \mathrm{~g} / \mathrm{kwh} \\
\text { Cons-Ngas for particular matter }=0.001 \times 50=0.05 \mathrm{~g} / \mathrm{kwh} \\
\text { Cons-elect for smog }=1.44 \times 50=72 \mathrm{~g} / \mathrm{kwh} \\
\text { Cons-Ngas for smog }=0.175 \times 50=8.75 \mathrm{~g} / \mathrm{kwh}
\end{gathered}
$$




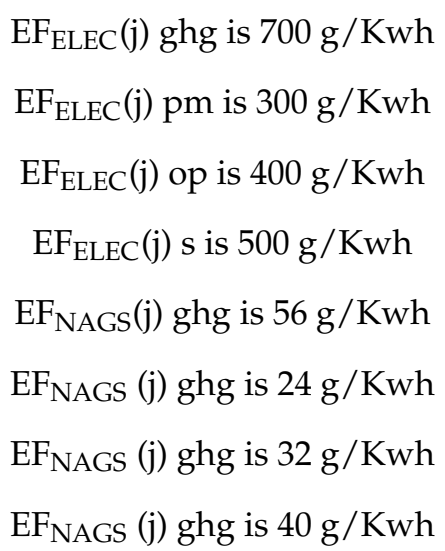

By applying Equations from (6) to (9):

$$
\begin{gathered}
\text { Eghg o } o^{\mathrm{p}}=(700 \times 35,000)+(56 \times 2775) \times 1=2605.4 \mathrm{~kg} / \mathrm{kwh} \\
\text { Epm o }^{\mathrm{p}}=(300 \times 4.5)+(24 \times 0.05)=1351.2 \mathrm{~kg} / \mathrm{kwh} \\
\text { Eap o }^{\mathrm{p}}=(400 \times 100)+(32 \times 0.05)=40.002 \mathrm{~kg} / \mathrm{kwh} \\
\text { Es o }^{\mathrm{p}}=(500 \times 72)+(40 \times 8.75)=36.25 \mathrm{~kg} / \mathrm{kwh}
\end{gathered}
$$

By applying Equation (11):

$$
\mathrm{E}^{\mathrm{tot}}=\mathrm{Ed}+\mathrm{Ed}^{\mathrm{i}}=0.1054+2.771=2.8764 \mathrm{Kg} \mathrm{CO}_{2}-\mathrm{Eq}
$$

The equivalent annual worth for labor cost, material cost, equipment cost, maintenance cost per year, maintenance cost per period of time, and number of single payments are 500,000 L.E/year, 2,000,000 L.E/ year, 10,000,000 L.E/year, 500,000 L.E/year, 40,000 L.E/year, and 1, respectively. Then, by applying Equation (14):

$$
\begin{aligned}
& \text { TLCC }=(\text { total life cycle cost })=500,000+2,000,000+10,000,000+500,000+40,000+ \\
& 1=1304,0001 \text { L.E } / \text { year }
\end{aligned}
$$

For project 1, the surface area of the project is $3240 \mathrm{~km}^{2}$, the life span of the project is 50 years, and the annual electricity consumption is $295.4 \mathrm{kwh} / \mathrm{m}^{2}$ (from interviews). Then, by applying Equations (16) and (17):

$$
\begin{gathered}
\text { TEC }=200 \times 3240 \times 50=32,400 \text { megajoules } \\
\text { TNGC }=295.4 \times 3240 \times 50=47,854.8 \text { megajoules }
\end{gathered}
$$

The total primary energy (PE) is computed based on Equation (15), where PE during manufacture, and transportation off-site phase is 77,890 megajoules, PE during the maintenance phase is 59,890 megajoules, PE during operational is 32,400 megajoules, PE during deconstruction, and demolition phase is 1628.2 megajoules, PE during the recycling and reuse phase is 84.24 megajoules, PE during the construction, and transportation on-site phase is 1890.8 megajoules (interviews, and AbdelKader [1]), then by applying Equation (15):

$$
\mathrm{TPE}=77,890+59,890+1890.8+32,400+1628.2+84.24=173,783.24 \text { Mega Joule }
$$

\subsection{Defining Output of the Proposed Model}

The sixth step is to compute time, life cycle, environmental impacts, and primary energy. The interface of the proposed model, which is used to compute the execution time for the asphalt construction, is depicted in Figure 5. The interface of life cycle cost assessment is depicted in Figure 6. 
The interface of the environmental impact calculation is depicted in Figure 7. The interface of primary energy computation is depicted in Figure 8.

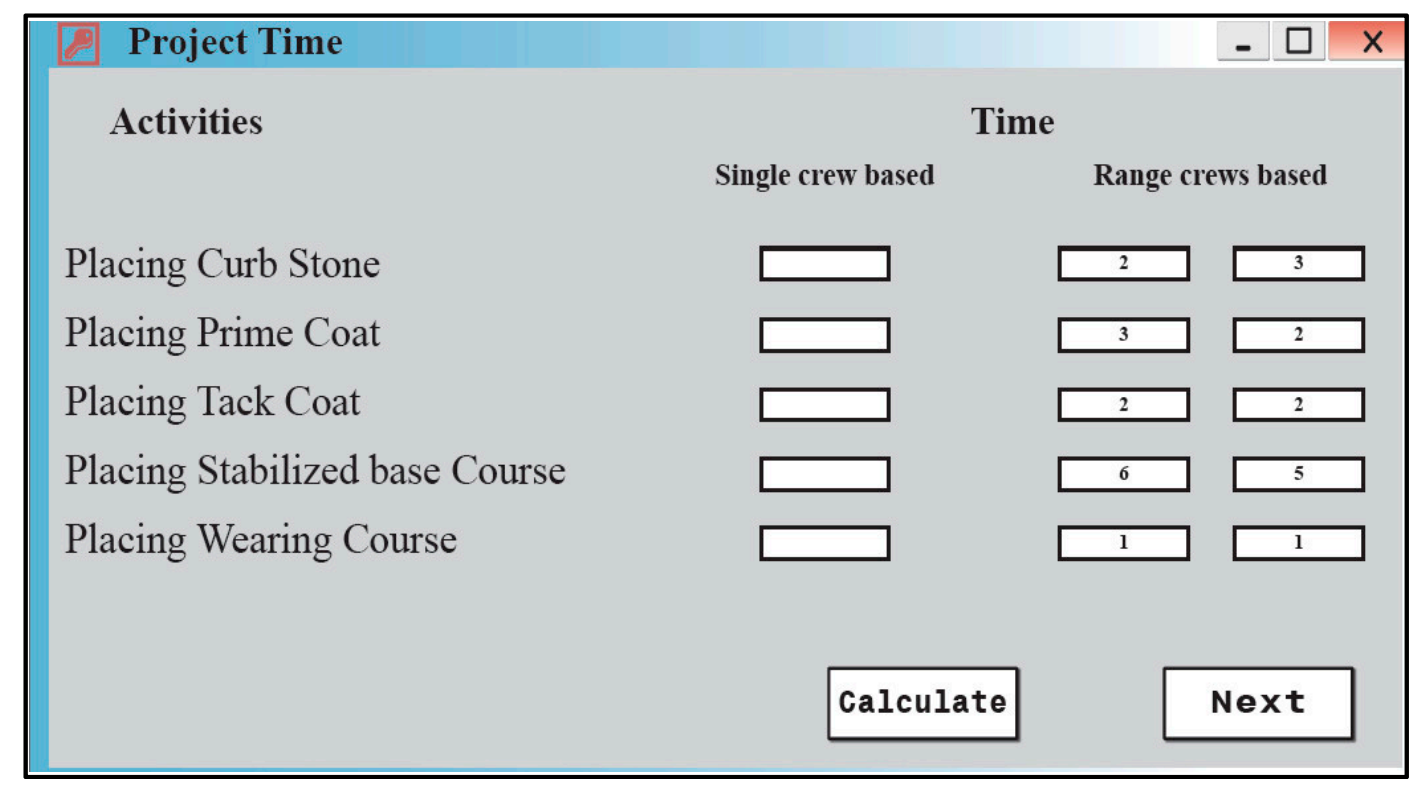

Figure 5. The time module calculations interface.

As illustrated in Figure 5, the interface of the time module asks the user to specify the type of the crew engaged in performing each certain road activity. The "next" button enables the user to transfer from one division to another. The "calculate" button enables the user to compute the parameter of specific division. The "convert" button enables the user to transform the results to Microsoft Excel.

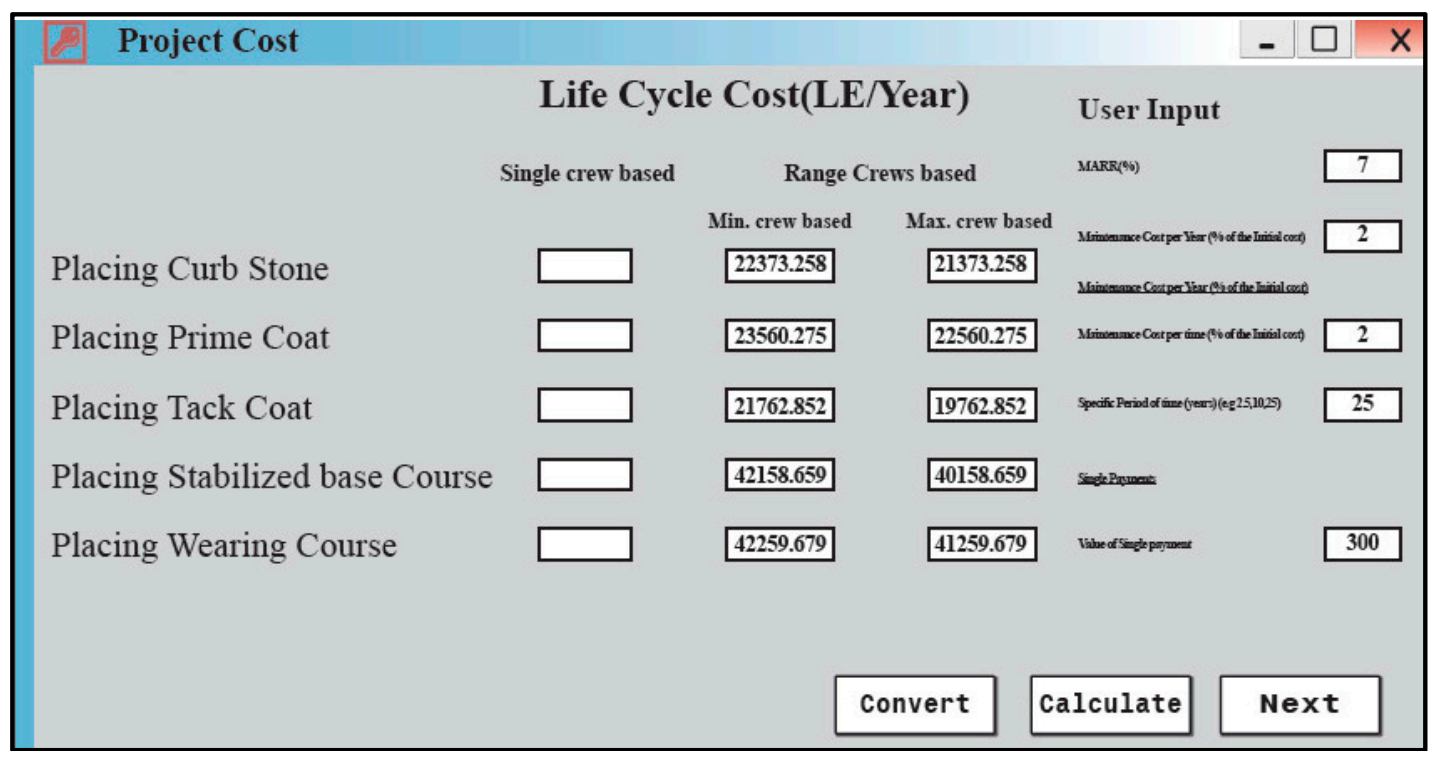

Figure 6. Cost module calculations interface.

As illustrated in Figure 6, the interface of the system computes life cycle cost for performing each road activity. The "next" button enables the user to transfer from one division to another. The "calculate" button enables the user to compute the parameter of specific division. The "convert" button enables the user to transform the results to Microsoft Excel. 


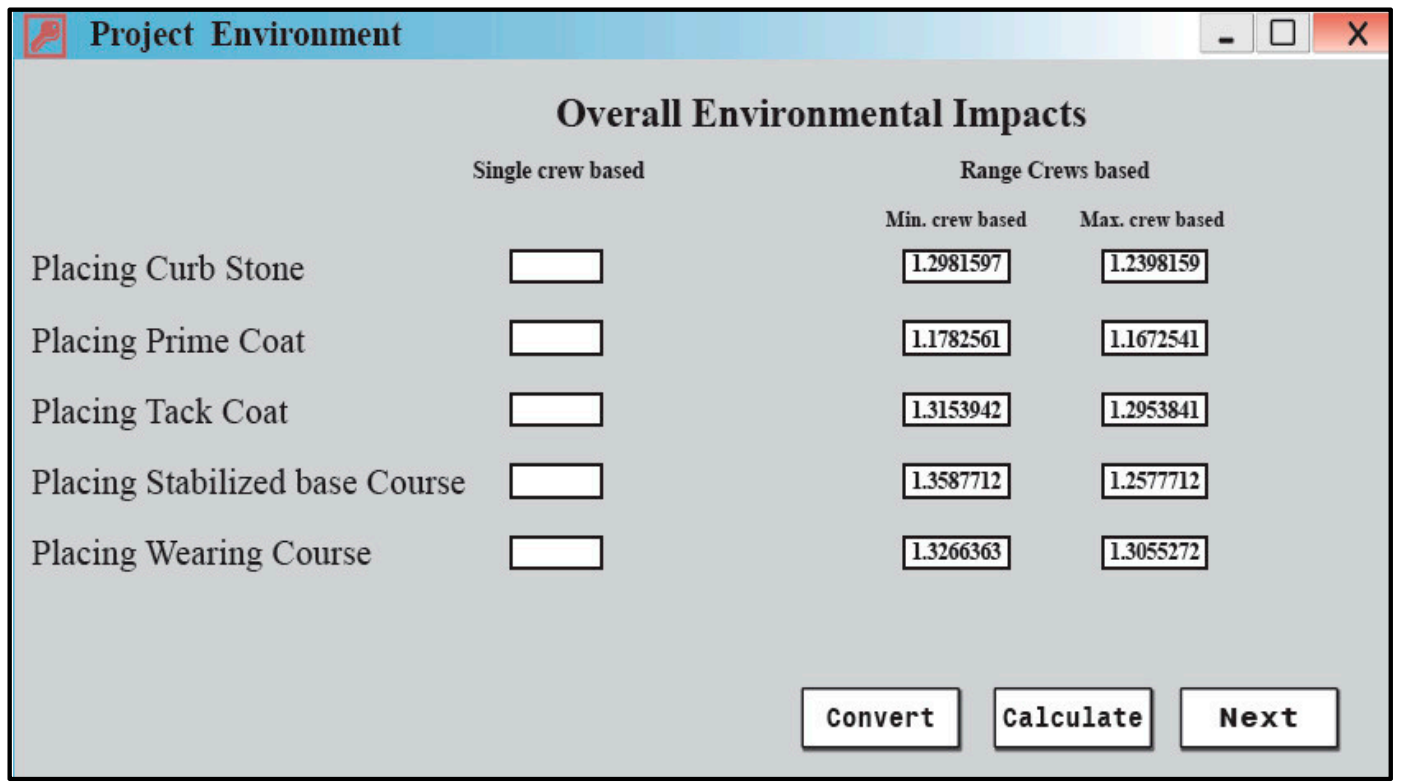

Figure 7. Environmental impact calculations interface.

As illustrated in Figure 7, the interface of the system computes the overall environmental impacts of performing each road activity. The "next" button enables the user to transfer from one division to another. The "calculate" button enables the user to compute the parameter of specific division. The "convert" button enables the user to transform the results to Microsoft Excel.

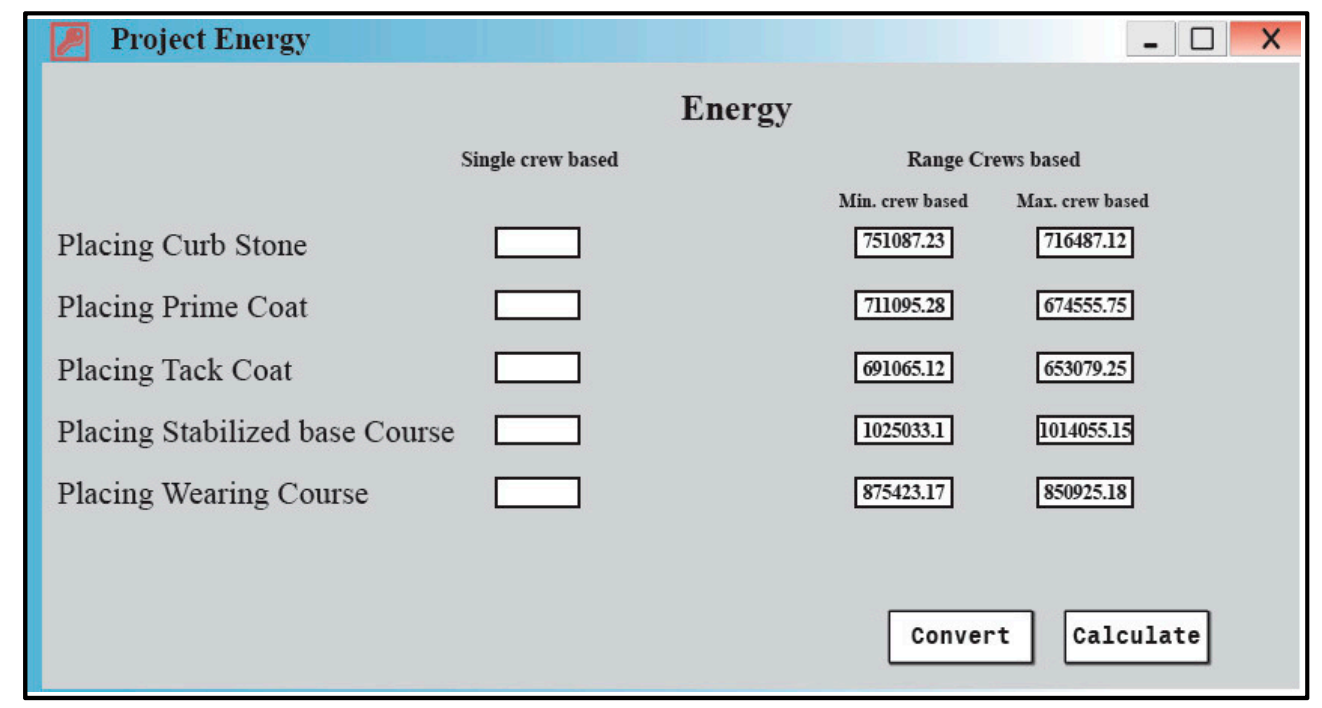

Figure 8. Primary energy calculations interface.

As illustrated in Figure 8, the system computes the road energy in performing each road activity. The "calculate" button enables the user to compute the parameter of specific division. The "convert" button enables the user to transform the results to Microsoft Excel.

\subsection{Conducting Comparative Case Study}

In this section, a comparative case study is conducted to demonstrate the results obtained from the above described model, and to validate the results by comparing the results obtained from the software with the results published from previous researchers. Table 6 lists the description of road 
construction projects that were used in the case study based on interviews with ten experts, each of them has more than twenty years of experience in road construction projects. Table 7 lists number of crews in performing each road construction activity in the six projects.

Table 6. Road construction project characteristics.

\begin{tabular}{ccccc}
\hline Project ID & Description & Length (KM) & Cost (Billion EGP.) & $\begin{array}{c}\text { Approximate } \\
\text { Finishing Date }\end{array}$ \\
\hline Project 1 & Asyut/ Sohag/Red Sea & 180 & 1.156 & 31 March 2016 \\
Project 2 & Qena/Safaga & 120 & 0.632 & 31 December 2016 \\
Project 3 & El-Alamein/Wadi El-Natroun & 135 & 2 & 1 January 2016 \\
Project 4 & Uyun Musa & 33 & 0.128 & 15 January 2016 \\
Project 5 & Ra's Gharib/Alsheikh Fadl & 90 & 0.317 & 28 February 2016 \\
Project 6 & Mena/Ra's Gharib & 55 & 0.625 & 30 April 2016 \\
\hline
\end{tabular}

Table 7. Road construction project activities and their equipment.

\begin{tabular}{ccccccc}
\hline Project Assemblies & \multicolumn{7}{c}{ Project No. } \\
\cline { 2 - 7 } & $\mathbf{1}$ & $\mathbf{2}$ & $\mathbf{3}$ & $\mathbf{4}$ & $\mathbf{5}$ & $\mathbf{6}$ \\
\hline Performing earthworks & 6 & 4 & 7 & 4 & 3 & 3 \\
Performing fill embankment & 5 & 3 & 6 & 3 & 2 & 2 \\
Placing sub-base & 5 & 2 & 6 & 2 & 2 & 2 \\
Placing curbstone & 5 & 2 & 6 & 2 & 2 & 2 \\
Insulating prime coat & 3 & 2 & 5 & 2 & 2 & 2 \\
Insulating tack coat & 3 & 2 & 5 & 2 & 2 & 2 \\
Placing stabilized base course & 5 & 2 & 6 & 2 & 2 & 2 \\
Placing wearing coarse & 5 & 2 & 6 & 2 & 2 & 2 \\
\hline Total & 37 & 19 & 47 & 19 & 17 & 17 \\
\hline
\end{tabular}

Table 8 lists the contribution of life cycles in producing different environmental impact indicators, and primary energy.

As listed in Table 8, the amount of environmental impacts and consumption of energy during both the construction and transportation phase, and the operating phase for Projects 1, 4, 5, and 6 is higher than the amount of environmental impacts and consumption of energy for project 4 , and 6 because of the characteristics of road construction and the number of crews. For example, project 1 has a length of $180 \mathrm{~km}$ and no of equipment working the project is 42 crews, while in project 4 , the length of the project is $33 \mathrm{~km}$ and the number of equipment working in the project is 15 . Thus, these characteristics of road project influence the amount of environmental impacts generated and the consumption of energy during the construction and transportation phase and the operating phase. On the other hand, other phases of road construction project for the six projects remain close to each other. Thus, mitigation strategies should be developed to overcome these situations.

As illustrated in Figure 9, the greenhouse gas emissions resulted from the excessive consumption of natural gas, oil, and coal substances. Due to the increase in urban development in Egypt nowadays, the Egyptian government has launched several new road projects. Thus, the usage of construction materials, and equipment has increased, which in turn lead to an increase in the amount of impact on green gas emissions. Greenhouse gas emissions may have a severe effect on the health of civilians indirectly [33]. 
Table 8. Total life cycles in producing different environmental impact indicators and primary energy.

\begin{tabular}{|c|c|c|c|c|c|c|c|c|}
\hline Project ID & Assembly & GHC $\left(\mathrm{Kg} \mathrm{CO}_{2}\right)$ & $\mathrm{AP}\left(\mathrm{Kg} \mathrm{So}_{2}\right)$ & $\mathrm{HH}\left(\mathrm{Kg} \mathrm{PM}_{2.5}\right)$ & $\mathrm{EP}(\mathrm{Kg} \mathrm{N})$ & OD (Kg CFC-11) & $\operatorname{Smog}\left(\mathrm{Kg} \mathrm{O}_{3}\right)$ & Energy (Mega-Joule) \\
\hline \multirow{6}{*}{ Project 1} & Manufacturing and transportation off-site phase & 17,000 & 7850 & 7550 & 7950 & 8820 & 19,250 & 77,890 \\
\hline & Construction, and transportation on-site phase & 2590 & 1980 & 510 & 450 & 550 & 1150 & 1890.8 \\
\hline & Recycling, and reuse phase & 4600 & 180 & 80 & 80 & 80 & 200 & 84.24 \\
\hline & Operating phase & 23,200 & 310 & 180 & 180 & 180 & 1400 & 32,400 \\
\hline & Maintenance phase & 32,400 & 890 & 650 & 750 & 800 & 15,590 & 59,890 \\
\hline & Deconstruction, and demolition phase & 350 & 150 & 130 & 110 & 100 & 295 & 1628.2 \\
\hline \multirow{6}{*}{ Project 2} & Manufacturing and transportation off-site phase & 16,150 & 8635 & 9060 & 7552.5 & 8731.8 & $20,982.5$ & 85,590 \\
\hline & Construction, and transportation on-site phase & 2460.5 & 2178 & 612 & 427.5 & 544.5 & 1253.5 & 1250 \\
\hline & Recycling, and reuse phase & 4370 & 198 & 96 & 76 & 79.2 & 218 & 80.028 \\
\hline & Operating phase & 22,040 & 341 & 216 & 171 & 178.2 & 1526 & 30,780 \\
\hline & Maintenance phase & 30,780 & 979 & 780 & 712.5 & 792 & $16,993.1$ & 45,980 \\
\hline & Deconstruction, and demolition phase & 332.5 & 165 & 156 & 104.5 & 99 & 321.55 & 1132 \\
\hline \multirow{6}{*}{ Project 3} & Manufacturing and transportation off-site phase & $16,957.5$ & 9930.25 & 10,419 & 7703.6 & 8906.4 & 25,179 & 81,985 \\
\hline & Construction, and transportation on-site phase & 2583.5 & 2504.7 & 703.8 & 436.1 & 555.39 & 1504.2 & 1125 \\
\hline & Recycling, and reuse phase & 4588.5 & 227.7 & 110.4 & 77.5 & 80.7 & 261.6 & 92 \\
\hline & Operating phase & 23,142 & 392.2 & 248.4 & 174.4 & 181.7 & 1831.2 & 35,397 \\
\hline & Maintenance phase & 32,319 & 1125.9 & 897 & 726.8 & 807.84 & $20,391.7$ & 32,950 \\
\hline & Deconstruction, and demolition phase & 349.1 & 189.8 & 179.4 & 106.6 & 100.98 & 385.86 & 1778 \\
\hline \multirow{6}{*}{ Project 4} & Manufacturing and transportation off-site phase & $16,618.5$ & 9433.7 & 130,235 & 8473.9 & 8728.3 & $22,661.1$ & 91,902 \\
\hline & Construction, and transportation on-site phase & 2531.8 & 2379.45 & 879.75 & 479.65 & 544.28 & 1353.78 & 2230.9 \\
\hline & Recycling, and reuse phase & 4496.73 & 216.315 & 138 & 85.272 & 79.16 & 235.44 & 99.398 \\
\hline & Operating phase & $22,679.1$ & 372.5 & 310.5 & 191.82 & 178.1 & 1648.08 & 38,228 \\
\hline & Maintenance phase & $31,672.6$ & 1069.58 & 1121.25 & 799.45 & 791.68 & $18,352.5$ & 70,664 \\
\hline & Deconstruction and demolition phase & 342.1 & 180.2 & 224.25 & 117.249 & 98.9 & 347.24 & 1921 \\
\hline \multirow{6}{*}{ Project 5} & Manufacturing and transportation off-site phase & $15,787.3$ & $10,848.8$ & $12,372.5$ & 8050.21 & 8291.92 & 21,528 & 89,307 \\
\hline & Construction, and transportation on-site phase & 2405.2 & 2736.4 & 835.7 & 455.6 & 517.07 & 1286.01 & 2559.3 \\
\hline & Recycling, and reuse phase & 4271.94 & 248.73 & 131.1 & 81.0084 & 75.2099 & 223.668 & 94.44 \\
\hline & Operating phase & $21,545.2$ & 428.4 & 294.975 & 182.29 & 169.23 & 1565.6 & 36,317 \\
\hline & Maintenance phase & $30,088.9$ & 1229.91 & 1065.18 & 759.48 & 752.09 & 17,434 & 47,131 \\
\hline & Deconstruction, and demolition phase & 325.04 & 207.3 & 213.40 & 111.39 & 94.01 & 329.93 & 1525.3 \\
\hline \multirow{6}{*}{ Project 6} & Manufacturing and transportation off-site phase & $18,944.9$ & $10,306.3$ & 12,991 & 7647.70- & 9121.01 & $25,833.6$ & 90,913 \\
\hline & Construction, and transportation on-site phase & 2886.3 & 2599.56 & 877.56 & 432.89 & 568.749 & 1543.39 & 2649.2 \\
\hline & Recycling, and reuse phase & 5126.22 & 236.3 & 137.655 & 76.98 & 82.7389 & 268.40 & 118.03 \\
\hline & Operating phase & 25,854 & 407.27 & 309.78 & 173.16 & 186.145 & 1878.81 & 45,396 \\
\hline & Maintenance phase & 36,106 & 1168.4 & 1118.45 & 721.48 & 827.389 & $20,921.9$ & 63,913 \\
\hline & Deconstruction, and demolition phase & 390.04 & 196.98 & 223.69 & 105.812 & 103.46 & 395.89 & 2281.4 \\
\hline
\end{tabular}

Notes: AP: acidification potential; HH: human health; EP: eutrophication potential; OD: ozone depletion. 


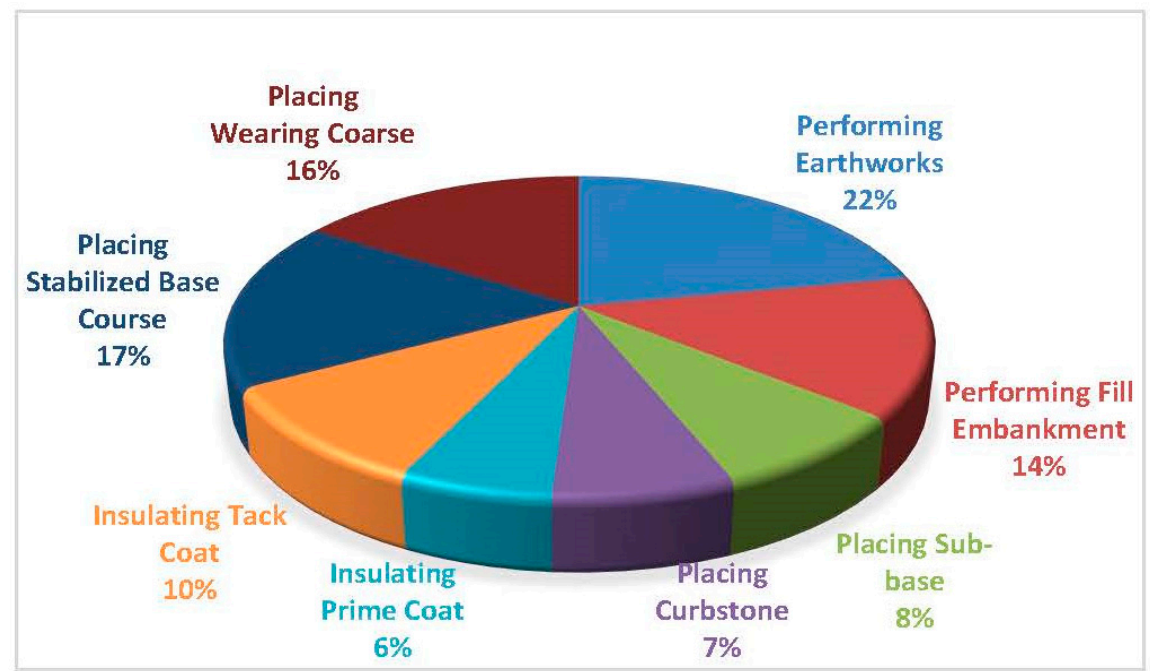

Figure 9. Contribution of different activities to the greenhouse gas (GHG) footprint.

As illustrated in Figure 10, the impact on acidification potential emissions resulted from the excessive usage of electricity, automobiles, and construction equipment. Because of the excessive usage of construction equipment (trucks, loaders, and excavators) during the process of road construction, an impact on acidification potential emissions has emerged. Impact on acidification potential emissions may have severe effect on the health of civilians (indirectly) through affecting water biota and terrestrial plants, animals, and plants. Impact on acidification potential can cause respiratory diseases, or can make these diseases worse. Respiratory diseases like asthma or chronic bronchitis make it hard for people to breathe. Also, ecological effects of acid rain are most clearly seen in aquatic environments, such as streams, lakes, and marshes where it can be harmful to fish and other wildlife. Dead or dying trees are a common sight in areas effected by acid rain. Acid rain leaches aluminum from the soil. That aluminum may be harmful to plants as well as animals. Acid rain also removes minerals and nutrients from the soil that trees need to grow.

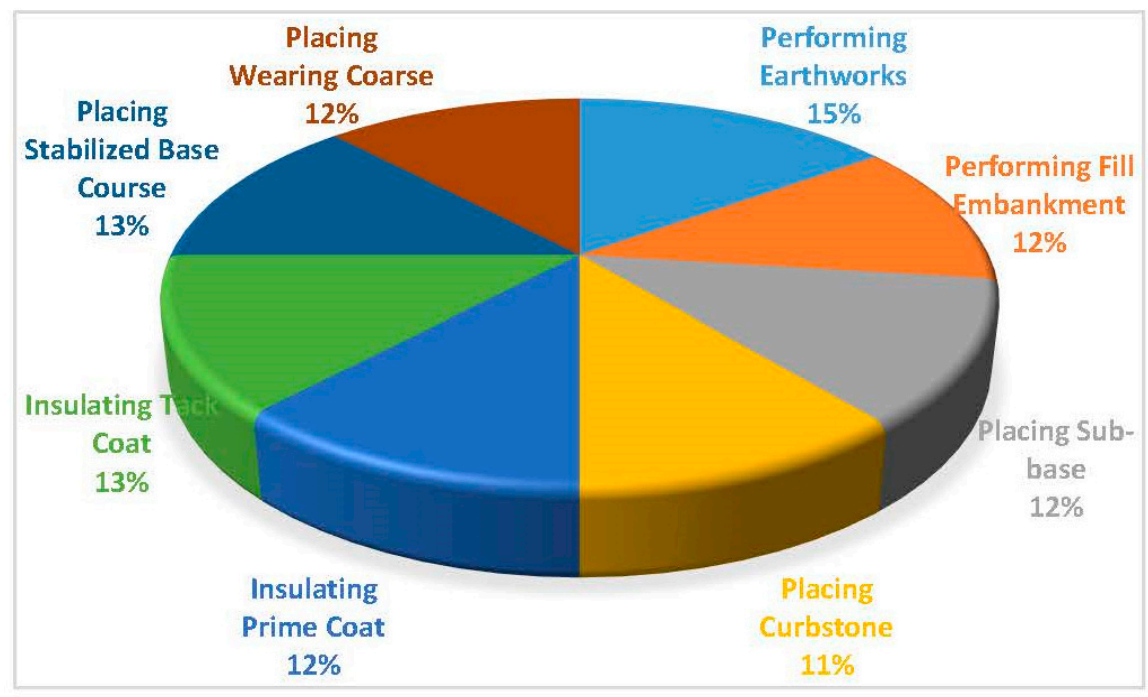

Figure 10. Contribution of different activities to acidification potential (AP).

As illustrated in Figure 11, the impact on particulate matter $(\mathrm{HH})$ potential emissions resulted from the usage of motor vehicles, and coal combustion. Because of the increase in the usage of construction equipment (trucks, loaders, and excavators) during the process of road construction due 
to the huge number of road projects under construction nowadays in Egypt, the amount of particulate matter $(\mathrm{HH})$ potential emissions has increased. Impact on acidification potential emissions may have severe effect on the health of civilians indirectly through polluting the air. Particulate matter $(\mathrm{HH}) \mathrm{can}$ cause mortality, and respiratory hospitalizations [34].

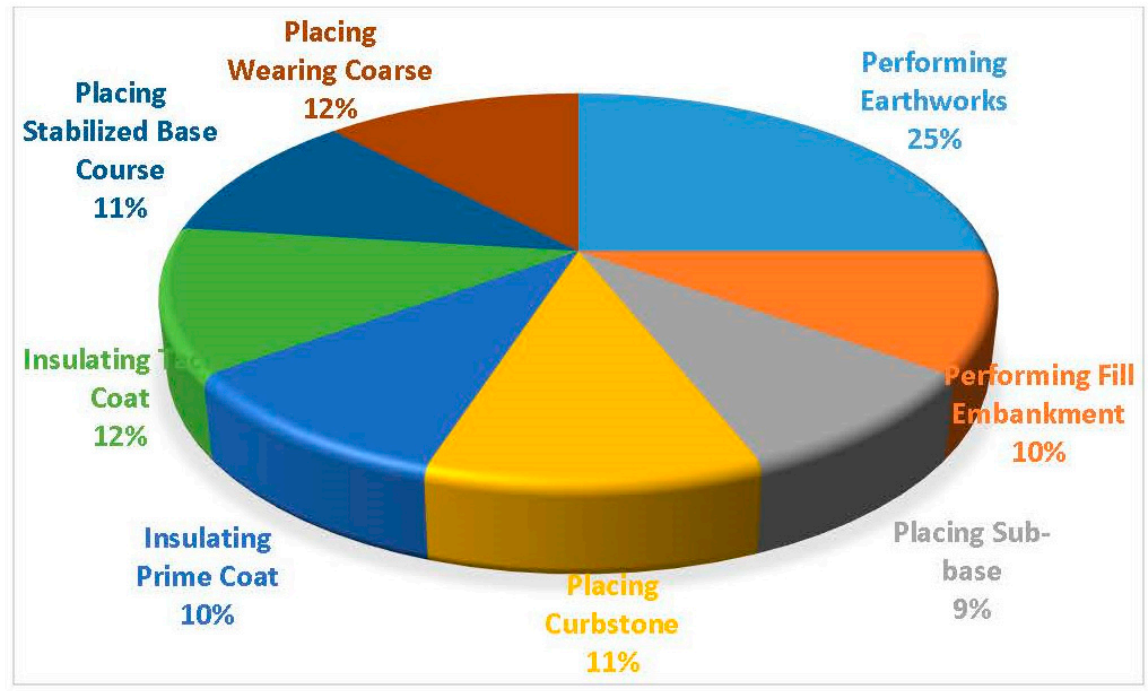

Figure 11. Contribution of different activities to particulate matter $(\mathrm{HH})$.

After that the difference in percentage was computed between the results obtained from the model and the results published by Park et al. [9]. Table 9 lists the difference in percent between the model and Park et al. [9] regarding the impact on greenhouse gas (GHG) footprint, impact on acidification potential (AP), impact on human health $(\mathrm{HH})$ particulate, impact on eutrophication potential (EP), impact on ozone depletion, and impact on smog. Table 10 lists the difference in percent between the model and Park et al. [9] regarding energy consumption.

Table 9. The difference in environmental impacts between the model and Park et al. [9].

\begin{tabular}{ccccccc}
\hline \multirow{2}{*}{ Assembly } & \multicolumn{7}{c}{ Project } \\
\cline { 2 - 7 } & $\mathbf{1}$ & $\mathbf{2}$ & $\mathbf{3}$ & $\mathbf{4}$ & $\mathbf{5}$ & $\mathbf{6}$ \\
\hline Manufacturing and transportation off-site phase & 3.49 & 2.63 & 2.44 & 18.61 & 1.18 & 4.98 \\
Construction, and transportation on-site phase & 3.89 & 3.96 & 3.96 & 1.39 & 4.22 & 4.24 \\
Maintenance phase & 0.05 & 0.98 & 1.18 & 19.26 & 2.73 & 1.02 \\
Deconstruction, and demolition phase & 0.4 & 0.39 & 0.39 & 0.79 & 0.36 & 0.34 \\
\hline
\end{tabular}

Notes: All values are expressed in percent.

Table 10. The difference in energy consumption between the model and Park et al. [9].

\begin{tabular}{ccccccc}
\hline Assembly & \multicolumn{7}{c}{ Project } \\
\cline { 2 - 7 } & $\mathbf{1}$ & $\mathbf{2}$ & $\mathbf{3}$ & $\mathbf{4}$ & $\mathbf{5}$ & $\mathbf{6}$ \\
\hline Manufacturing and transportation off-site phase & 1.88 & 6.9 & 12.57 & 1.88 & 6.55 & 0.09 \\
Construction, and transportation on-site phase & 0.42 & 0.83 & 0.81 & 0.42 & 0.06 & 0.1 \\
Maintenance phase & 2.39 & 5.67 & 12.04 & 2.39 & 6.46 & 0.01 \\
Deconstruction, and demolition phase & 0.14 & 0.44 & 0.22 & 0.14 & 0.2 & 0.14 \\
\hline
\end{tabular}

Notes: All values are expressed in percent.

Then interviews were held with the previously mentioned experts to justify why this average percentage error occurred. Experts replied that data collected for the case study is the approximately measuring the input variables, such as the number of crossing construction, and passenger cars roads 
per day. Also, the ratio of passengers' cars to construction trucks were approximately computed by average/day. Moreover, they pointed out that there should be official statistics about the number of cars crossing each road per day. Experts were then asked to propose a set of mitigation strategies in order to reduce the amount of environmental impact indicators resulted from operation in road construction projects. They finally pointed out nine mitigation strategies that should be implemented in order to reduce the amount of environmental impacts. These mitigation strategies will be used in another model that is capable of reducing the amount of construction wastes generated in road construction projects using system dynamics, which is currently under preparation. The nine mitigation strategies that should be implemented are listed below:

1. Educate road construction projects participants about the importance of environmental impact indicators management and its drawbacks on the environment and the health of civilians.

2. The infrastructure construction firms should adopt international standards, such as the environmental management systems (EMS), which allow the firm to identify opportunities for reducing the environmental impact indicators of its day-to-day operations.

3. The infrastructure construction firms must adopt the latest environmental technologies in order to reduce the amount of environmental impact indicators, such as those proposed in environmental technology policies Environmental Protection Agency (EPA). The EPA program provides the verification process for the performance of innovative environmental technologies in a particular application. In the construction sector, the EPA program has largely been concerned with the technologies for emission reductions, such as after-treatment technologies, use of cleaner fuel, and emission-reducing fuel additives. The EPA rules for off-road diesel engines are the regulations with the biggest impact on emissions from construction equipment. Thus, equipment manufacturers are required to ensure their products comply with these regulations with a standardized certification test for their products.

4. Environmental impact indicators incentives should be granted to construction firms that adopt best practices; these incentives include: grant programs, which provide direct funding to equipment owners to replace old equipment with new and cleaner equipment, and tax incentives, which offer tax exemptions, tax deduction, or tax credits to adopt the usage of technologies for reducing emissions.

5. Increase the amount construction equipment operating with natural gas, rather than diesel. By applying this strategy, the amount of environmental impacts will be lessened.

6. The government must adopt legislation that encourages the expand of biofuel and decreasing the number of equipment operating with natural gas and diesel.

7. Replacement of non-renewable natural aggregates by recycled aggregates and in particular secondary aggregates obtained from industrial wastes and by products.

8. Use of recycling techniques in road rehabilitation projects especially in-place recycling.

9. Use of cold asphalt mixes instead of hot asphalt mixes.

\section{Conclusions}

A three-dimensional BIM module was developed that is capable of computing time, life cycle cost, overall environmental impacts, and primary energy associated with road construction processes, using Revit 2015 software, the Athena Impact Estimator, and Copert software version4. The results obtained from the model demonstrated that the environmental impact indicators have negative consequences for both the environment and individuals. A set of mitigation strategies were developed to overcome these negative consequences. Thus, the government should adapt strong legislations to encourage waste management procedures, and reduction in the overall environmental impacts. The model can be applied to any other type of construction project, and any developing country by changing the environmental impact indicators contributors, data, and experts' judgment. The results of the proposed 
model will be introduced to another model that mitigates, and reduces the amount of wastes generated in road construction projects using system dynamics, which is currently under preparation.

Acknowledgments: This research did not receive any specific grant from funding agencies in the public, commercial, or not-for-profit sectors.

Author Contributions: Mohamed Marzouk conceived and designed the research framework. Mohamed El-zayat and Ahmed Aboushady conducted the research and analyzed the case results. Ahmed Aboushady reviewed the related literature and extensively revised and edited the whole manuscript. All authors read and approved the final manuscript.

Conflicts of Interest: The authors declare no conflict of interest.

\section{References}

1. Abdelhader, E.A. Optimizing Construction Emissions for Sustainable Construction Projects. Master's Thesis, Faculty of Engineering, Cairo University, Giza, Egypt, 2016.

2. Rani, B.; Singh, U.; Chuhan, A.; Sharma, D.; Maheshwari, R. Photochemical Smog Pollution and its mitigation measures. J. Adv. Sci. Res. 2011, 2, 28-33.

3. Abanda, F.H.; Tah, J.H.M.; Cheung, F.K.T. Mathematical Modelling of Embodied Energy, Greenhouse Gases, Waste, Time-Cost Parameters of Building Projects: A Review. Build. Environ. 2013, 59, 23-37. [CrossRef]

4. Tsai, W.-H.; Yang, C.-H.; Chang, J.-C.; Lee, H.-L. An Activity-Based Costing Decision Model for Life Cycle Assessment in Green Building Projects. Eur. J. Oper. Res. 2014, 238, 607-619. [CrossRef]

5. Hawken, P.; Lovins, A.B. Natural Capitalism: The Next Industrial Revolution; Earthscan: New York, NY, USA, 2010.

6. Holden, E.; Linnerad, K.; Banister, D. The Imperatives of Sustainable Development. Sustain. Dev. 2016. [CrossRef]

7. Umer, A.; Hewage, K.; Haider, H.; Sadiq, R. Sustainability assessment of roadway projects under uncertainty using Green Proforma: An index-based approach. Int. J. Sustain. Built Environ. 2016. [CrossRef]

8. Lim, S.R.; Suh, S.; Kim, J.H.; Park, H.S. Urban water infrastructure optimization to reduce environmental impacts and costs. J. Environ. Manag. 2010, 91, 630-637. [CrossRef] [PubMed]

9. Park, K.; Hwang, Y.; Seo, S.; Seo, H. Quantitative Assessment of Environmental Impacts on Life Cycle of Highways. J. Constr. Eng. Manag. 2003, 1, 25-31. [CrossRef]

10. Captiao, S.D.; Picado-Santos, L.G.; Martinho, F. Pavement Engineering Materials: Review of the use of Warm-Mix Asphalt. Constr. Build. Mater. 2012, 36, 1016-1024. [CrossRef]

11. Barandica, J.M.; Fernandez-Sanchez, G.; Berzosaa, A.; Delgodoa, J.; Acosta, F.J. Applying life cycle thinking to reduce greenhouse gas emissions from road projects. J. Clean Prod. 2013, 57, 79-91. [CrossRef]

12. Marzouk, M.; Abdel, A.A. Maintaining Subway Infrastructure Using BIM. Constr. Res. Congr. 2012. [CrossRef]

13. Marzouk, M.; Hisham, M. Implementing earned value management using bridge information modeling. KSCE J. Civ. Eng. 2014, 28, 1302-1313. [CrossRef]

14. Marzouk, M.; Abdel, A.A. Monitoring thermal comfort in subways using building information modeling. Energy Build. 2014, 84, 252-257. [CrossRef]

15. Jullien, A.; Dauvergne, M.; Proust, C. Road LCA: The dedicated ECORCE and database. Int. J. Life Cycle Assess. 2015, 20, 655-670. [CrossRef]

16. Kutz, M. Handbook of Transportation Engineering, 2nd ed.; Hard Cover: New York, NY, USA, 2011; Volume 2.

17. Cass, D.; Mukherjee, A. Calculation of Greenhouse Gas Emissions for Highway Construction Operations Using a Hybrid Life-Cycle Assessment Approach: Case Study for Pavement Operations. J. Constr. Eng. Manag. 2011, 137, 1015-1026. [CrossRef]

18. Flower, D.J.M.; Mitchell, V.G.; Codner, G.P. Urban water Systems: Drivers of Climate Change? In Rain Water and Urban Design; Barton, A.C.T., Ed.; Engineers Australia, 2007; pp. 274-281. Available online: www.greenfleet.com.au/.../Urban-Water-Systems-Drivers-of-Climate (accessed on 23 August 2007).

19. Angrill, S.; Farreny, R.; Gasol, C.M.; Gabarrell, X.; Viñolas, B.; Josa, A.; Rieradevall, J. Environmental Analysis of Rainwater Harvesting Infrastructures in Diffuse and Compact Urban Models of Mediterranean Climate. Int. J. Life Cycle Assess. 2012, 17, 25-42. [CrossRef]

20. Micheals, B. Intermodal Container Transfer Facility Joint Powers Authority. 2013. Available online: http:/ / www.ictf-jpa.org/past_events.php (accessed on 15 May 2013).

21. Flower, D.J.M.; Sanjayan, J.G. Green House Gas Emissions due to Concrete Manufacture. Int. J. Life Cycle Assess. 2007, 12, 282-288. [CrossRef] 
22. Mclellan, B.C.; Williams, R.P.; Riessen, A.V.; Corder, G.D. Costs and Carbon Emissions for Geopolymer Pastes in Comparison to Ordinary Portland Cement. J. Clean. Prod. 2011, 19, 1080-1090. [CrossRef]

23. Hong, J.; Shem, G.Q.; Feng, Y.; Lau, W.S.; Mao, C. Greenhouse Gas Emissions during the Construction Phase of a Building: A Case Study in China. J. Clean. Prod 2014, 103, 249-259. [CrossRef]

24. Pidgeon, N.; Fischhoff, B. The role of Social and Decision Sciences in Communicating Uncertain Climate Risks. J. Nat. Clim. Chang. 2011, 1, 35-41. [CrossRef]

25. EPA (U.S. Environmental Protection Agency). eGRID2012 Version 1.0. Available online: http://www.epa. gov/cleanenergy/energy-resources/egrid/index.html (accessed on 10 May 2013).

26. NREL. U.S. LCI Database; National Renewable Energy Laboratory: Golden, CO, USA, 2005. Available online: www.nrel.gov/lci (accessed on 6 June 2005).

27. IEA. Energy Balance for Egypt, 2006; International Energy Agency: Paris, France, 2009; Available online: https:/ / www.iea.org/countries/non-membercountries/egypt/ (accessed on 30 September 2009).

28. MSEA. Misr State Environmental Association Annual Report; Misr State Environmental Association: Cairo, Egypt, 2008.

29. Jalaei, F.; Jrade, A. An Automated BIM Model to Conceptually Design, Analyze, Simulate, and Assess Sustainable Building Projects. J. Constr. Eng. 2014, 14, 1-22. [CrossRef]

30. Figueras, A. Electricity in Egypt: The Whole Picture. 2016. Available online: http://www.egyptoil-gas.com/ publications/electricity-in-egypt-the-whole-picture/ (accessed on 28 January 2016).

31. Viswanathan, B. An Introduction to Energy Management. 2006. Available online: http://nccr.iitm.ac.in/ ebook\%20final.pdf (accessed on 21 May 2006).

32. Aye, L.; Ngo, T.; Crawford, R.H.; Gammampila, R.; Mendis, P. Life Cycle Greenhouse Gas Emissions and Energy Analysis of Prefabricated Reusable Building Modules. J. Energy Build. 2012, 47, 159-168. [CrossRef]

33. Department of Energy and Climate Change. 2013 UK Greenhouse Gas Emissions, Provisional Figures and 2012 UK Greenhouse Gas Emissions, Final Figures by Fuel Type and End-User Statistical Release. 2014. Available online: http://www.gov.uk/government/Uploads/attachment_data/file/295968/20140327_ 2013_UKGreenhouse_Gas_Emissions_Provisional_Figures.pdf (accessed on 27 March 2014).

34. World Health Organization. Health Risks of Particular Matter from Long-Range Transboundary Air Pollution. 2006. Available online: http://www.euro.who.int/data/assets/pdf_file/0006/78657/E88189.pdf (accessed on January 2006).

(C) 2017 by the authors. Licensee MDPI, Basel, Switzerland. This article is an open access article distributed under the terms and conditions of the Creative Commons Attribution (CC BY) license (http://creativecommons.org/licenses/by/4.0/). 